\title{
GAMBARAN ANSIETAS KELUARGA SAAT MENGHADAPI KEKAMBUHAN ANGGOTA KELUARGA DENGAN PENYAKIT KRONIS
}

\author{
Livana $\mathbf{P H}^{2}$, Sih Ayu Watini ${ }^{2}$, Rita Kartika Sari ${ }^{3}$ \\ ${ }^{1}$ Program Studi Ners, Sekolah Tinggi Ilmu Kesehatan Kendal \\ ${ }^{2}$ Psikiater, RSUD Dr.H Soewondo Kendal \\ ${ }^{3}$ Fakultas Kedokteran, Universitas Islam Sultan Agung Semarang \\ Email: livana.ph@gmail.com
}

\begin{abstract}
ABSTRAK
Penyakit kronis merupakan kondisi (penyakit) yang berlangsung dalam waktu lama dan secara terus menerus. Beberapa penyakit kronis yang ada di masyarakat diantaranya yaitu penyakit diabetes melitus, hipertensi, dll. Tujuan penelitian ini untuk mengetahui gambaran ansietas keluarga saat menghadapi kekambuhan anggota keluarga dengan penyakit kronis. Penelitian merupakan penelitian kuantitatif deskriptif,dengan jumlah sampel 64 responden. Tingkat ansietas keluarga diukur menggunakan kuesioner DASS terkait ansietas yang terdiri dari 14 pertanyaan. Hasil penelitian menunjukkan bahwa keluarga mayoritas mengalami ansietas pada tingkat ansietas sedang. Perlunya pelayanan kesehatan berbasis keluarga dan komunitas untuk meningkatkan kemampuan keluarga dalam mengatasi ansietas sehingga mampu merawat anggota keluarga dengan penyakit kronis.
\end{abstract}

Kata Kunci : Ansietas, keluarga, penyakit kronis

\section{DETERMINE THE IMAGE OF FAMILY ANXIETY WHEN FACING THE RECURRENCE OF FAMILY MEMBERS WITH CHRONIC DISEASES}

\begin{abstract}
Chronic illness is a condition (illness) that lasts for a long time and continuously. Some chronic diseases that exist in the community such as diabetes mellitus, hypertension, etc. The aims of this study to determine the image of family anxiety when facing the recurrence of family members with chronic diseases. This research is a descriptive quantitative research, with total sample 64 respondents. The level of family anxiety was measured using an anxiety-related DASS questionnaire consisting of 14 questions. The results showed that the majority families experienced anxiety at the level of moderate anxiety. The need for family and community-based health services to improve the ability of families in overcoming anxiety so as to care for family members with chronic diseases.
\end{abstract}

Keywords: Anxiety, family, chronic illness

\section{PENDAHULUAN}

Individu dengan penyakit kronis dapat menimbulkan kondisi dimana individu harus menjalani pengobatan serta perawatan secara rutin. Berbagai macam prosedur atau tindakan asing yang harus dijalani individu seperti nyeri yang dirasakan dapat menimbulkan ansietas (Gunarsa, 2010). Penelitian yang dilakukan PH, Keliat dan Susanti (2015), menunjukan bahwa 56 dari 100 pasien ansitas yang dirawat di rumah sakit merupakan pasien yang baru pertama kali dirawat di rumah sakit.

Ansietas tidak saja memperlihatkan gejala gejala perilaku ansietas, tetapi dapat juga memperlihatkan gejala perilaku fobia dan obsesif (Townsend, 2010). Prevalensi ansietas diperkirakan $20 \%$ dari populasi dunia menderita ansietas (Stuart, 2013). Menurut data National Institute of Mental Health (2005), di Amerika Serikat dilaporkan bahwa diperkirakan 1 dari 10 orang mengalami ansietas, dan terdapat 40 juta orang mengalami ansietas pada usia 18 tahun sampai pada usia lanjut. Ansietas merupakan gangguan kejiwaan yang menempati peringkat ke empat dari semua masalah gangguan kejiwaan di Amerika. Prevalensi ansietas di Indonesia berkisar antara $2-5 \%$ dari populasi umum atau $7-16 \%$ dari semua penderita gangguan jiwa. Indonesia merupakan negara yang setiap tahun prevalensi ansietasnya mengalami peningkatan (Hawari, 2011). Ansietas merupakan kelompok gangguan psikiatri yang sering ditemukan dan salah satu dampak dari 
gangguan mental emosional (Soetejo, 2011). Prevalensi gangguan mental emosional di Indonesia sebesar $6,0 \%$ (37.728 orang dari subyek yang dianalisis). Jawa tengah prevalensi gangguan mental emosional mencapai 4,7\% (Riskesdas, 2013).

Ansietas yang terjadi pada individu dengan penyakit kronis juga memberikan dampak pada keluarga yang merawatnya. Dampak adanya anggota keluarga yang menderita penyakit kronis diantaranya perubahan rutinitas keluarga yang diartikan sebagai beban. Beban yang dirasakan keluarga mengakibatkan ansietas. Seperti halnya dalam penanganan penyakit kronis diabetes melitus (DM). Dukungan keluarga dalam penanganan penyakit DM sangatlah diperlukan. Kendala utama penanganan pasien DM adalah kejenuhan pasien dalam kepatuhan dalam program pengobatan, hal inilah yang menyebabkan keluarga mengalami ansietas. Hal ini sesuai dengan hasil penelitian Arifin (2015) yang mengungkapkan bahwa ada hubungan signifikan antara dukungan keluarga dengan kepatuhan diet DM Tipe 2. Hal ini sejalan dengan penelitian Hasbi (2012) mengungkapkan bahwa faktor yang paling mempengaruhi penderita DM dalam melakukan olahraga adalah dukungan keluarga.

Bentuk peran keluarga untuk memberikan dukungan terhadap individu deengan penyakit kronis ditunjukkan dengan kemampuan keluarga dalam merawat anggota keluarganya. Upaya keluarga yang dapat dilakukan sebelum merawat keluarga dengan penyakit kronis yaitu dengan mengetahui tingkat ansietas yang dialami keluarga, sehingga diharapkan keluarga mampu menghadapi kekambuhan anggota keluarga yang menderita penyakit kronis.

Hasil studi pendahuluan yang dilakukan, didapatkan 3 dari 5 keluarga (caregiver) yang menghadapi kekambuhan anggota keluarga deengan penyakit kronis mengalami ansietas. 2 dari 3 keluarga (caregiver) tersebut mengalami ansietas sedang dan 1 keluarga (caregiver) mengalami ansietas berat. Berdasarkan latarbelakang tersebut peneliti tertarik melakukan penelitian yang bertujuan untuk mengetahui gambaran ansietas keluarga (caregiver) saat menghadapi kekambuhan anggota keluarga dengan penyakit kronis.

\section{METODE}

Penelitian ini merupakan penelitian deskriptif, dengan jumlah sampel 64 responden. Populasi pada penelitian ini adalah semua caregiver yang mempunyai anggota keluarga dengan penyakit kronis. Tehnik pengambilan sampel dengan cara consecutive sampling. Tingkat ansietas keluarga diukur menggunakan kuesioner DASS terkait ansietas yang terdiri dari 14 pertanyaan.

\section{HASIL}

Karakteristik Responden dapat dilihat paa tabel 1. Seedangkan gambaran tingkat ansietas responden dapat ilihat pada tabel 2 .

\section{PEMBAHASAN}

Hasil penelitian menunjukkan bahwa mayoritas responden mengalami ansietas pada tingkat sedang. Hal ini sesuai dengan pendapat Kuraesin (2009) ansietas terjadi pada indiviu yang mendapatkan tindakan asing saat dirawat di RS, hal ini dikarenakan belum pernah dirawat sebelumnya sehingga tidak mempunyai pengalaman, sedangkan pengalaman pertama klien ketika dirawat di rumah sakit merupakan pengalaman yang penting bagi kondisi mental individu itu sendiri. Peneliti berpendapat bahwa sama halnya dengan keluarga saat menghadapi kekambuhan anggota keluarga dengan penyakit kronis juga mengalami ansietas karena belum mempunyai pengalaman sebelumnya cara untuk menghadapi kekambuhan anggota keluarga dengan penyakit kronis.

Hasil penelitian ini juga sejalan dengan teori Potter dan Perry (2005) yang mengatakan bahwa penyebab ansietas pada individu diakibatkan dari nyeri yang dirasakan ataupun berbagai macam prosedur tindakan asing yang harus dijalani individu, ketakutan akan kematian, dan kekhawatiran akan ketidakberhasilan medikasi yang dijalani. Pendapat tersebut juga didukung oleh penelitian Elan (2014) bahwa sebagian besar pasien di Instalasi gawat Darurat yang mengalami tingkat ansietas berat. Adapun gejala ansietas yang muncul diantarananya inividu belum mempunyai pengalaman 
dirawat, gelisah, sering terbangun pada malam hari, khawatir, dan lain-lain. Hal tersebut disebabkan respon ansietas individu tergantung pada kematangan pribadi individu tersebut, pemahaman dalam menghadapi tantangan, harga diri, dan mekanisme koping yang digunakan. Hal ini senada dengan Teori Hawari (2011) bahwa ansietas merupakan keadaan emosional yang mempunyai ciri keterangsangan fisiologis, perasaan tegang yang tidak menyenangkan dan perasaan aprehensif bahwa suatu yang buruk akan terjadi. Pendapat tersebut juga sesuai teori Stuart (2013) bahwa ansietas mempunyai makna sebagai rasa kekhawatiran akan kegagalan terhadap harapan yang diinginkan. Perasaan tegang yang ada pada diri seseorang, yang mendorong secara implisit menyebabkan individu berfikiran secara tidak rasional dan emosional cenderung mendominasi setiap aktivitas yang akan dilakukan.

Tabel 1.

Karakteristik Responden ( $\mathrm{n}=64)$

\begin{tabular}{|c|c|c|}
\hline Variabel & $\mathrm{f}$ & $\%$ \\
\hline \multicolumn{3}{|l|}{ Jenis Kelamin } \\
\hline Laki-laki & 28 & 44 \\
\hline Perempuan & 36 & 56 \\
\hline \multicolumn{3}{|l|}{ Usia } \\
\hline $12-18$ & 2 & 3 \\
\hline$>18-25$ & 3 & 5 \\
\hline$>25-60$ & 55 & 86 \\
\hline$>60$ & 4 & 6 \\
\hline \multicolumn{3}{|l|}{ Pendidikan } \\
\hline Tidak sekolah & 7 & 11 \\
\hline SD & 33 & 51 \\
\hline SLTP & 12 & 19 \\
\hline SLTA & 9 & 14 \\
\hline PT & 3 & 5 \\
\hline \multicolumn{3}{|l|}{ Pekerjaan } \\
\hline Pelajar & 3 & 5 \\
\hline IRT & 11 & 17 \\
\hline Buruh & 29 & 45 \\
\hline Wiraswasta & 10 & 16 \\
\hline Pedagang & 10 & 16 \\
\hline PNS & 1 & 1 \\
\hline \multicolumn{3}{|c|}{ Hubungan responden dengan anggota keluarga yang menderita penyakit kronis } \\
\hline Anak & 36 & 56 \\
\hline Suami/ istri & 14 & 22 \\
\hline orangtua & 4 & 6 \\
\hline Saudara & 10 & 16 \\
\hline
\end{tabular}

Tabel 2.

Gambaran Tingkat Ansietas responden $(\mathrm{n}=64)$

\begin{tabular}{lcc}
\multicolumn{1}{c}{ Tingkat ansietas } & $\mathrm{f}$ & $\%$ \\
\hline Ringan & 3 & 5 \\
\hline Sedang & 24 & 37 \\
\hline Berat & 37 & 58 \\
\hline
\end{tabular}

SIMPULAN DAN SARAN

Simpulan

Karakteristik keluarga yang mengalami ansietas saat menghadapi kekambuhan anggota keluarga dengan penyakit kronis sebagian besar berjenis kelamin perempuan berusia $>25$ 60 tahun, bekerja sebagai buruh, tingkat pendidikan SD, hubungan dengan penderita 
sebagai anak. Tingkat ansietas yang dialami keluarga mayoritas berada pada ansietas tingkat sedang.

\section{Saran}

Perlunya pelayanan kesehatan berbasis keluarga dan komunitas untuk meningkatkan kemampuan keluarga dalam mengatasi ansietas sehingga mampu merawat anggota keluarga dengan penyakit kronis.

\section{DAFTAR PUSTAKA}

Elan. (2014). Gambaran Tingkat Kecemasan Pasien Di Instalasi Gawat Darurat RSUD Penambahan Senopati Bantul.

Gunarsa, Singgih. D. (2010). Bunga rampai psikologi perkembangan: Dari anak sampai usia lanjut. Jakarta: PT BPK Gunung Mulia.

Hawari, D. (2011). Manajemen Stres, Cemas Dan Depresi. Jakarta: FKUI. Townsend. (2010), Buku saku Diagnosis Keperawatan Psikiatri: Rencana Asuhan dan Medikasi Psikotropik (Edisi 5). Jakarta. EGC.

Kuraesin, N. D (2009). Faktor-faktor yang mempengaruhi tingkat kecemasan pasien yang akan menghadapi operasi di RSUP Fatmawati. Universitas Islam Negeri Syarif Hidayatullah Jakarta.

PH. Livana, Keliat. B.A, Putri, Y.S.E. (2015). the effect of generalist and specialist therapies (thought stopping and progressive muscle relaxation) in reducing anxiety response of clients with physical illness in Dr.H.Marzoeki hospital of Bogor. Proceeding book The 2nd International Confrence on Health Science 11 Oktober 2015. ISBN : 978602-73585-0-8: Poltekes Kemenkes Yogyakarta.

http://poltekkesjogja.ac.id/wpcontent/uploads/2016/01/ProsidingICHS.pdf

Potter \& Perry. (2005). Fundamental Keperawatan. Jakarta : EGC.

Riskesdas. (2013). Laporan Hasil Kesehatan Dasar. Badan Penelitian dan
Pengembangan Kesehatan Departemen Kesehatan RI.

Soetejo, dkk. (2011). Penurunan Ansietas Melalui Looterapi Kelompok Pada Kelompok Pada Penduduk Pasca-Gempa Di Kabupaten Klaten. Jurusan Keperawatan Poltekkes Kemenkes Yogyakarta. Yogyakarta: Jurnal Keperawatan Indonesia.

Stuart, Gail W. (2013). Principles \& Practice of Psychiatric Nursing. edisi 9. Philadelphia : Elsevier Mosby.

Stuart. (2006). Buku Saku Keperawatan Jiwa, edisi 5. Jakarta : EGC. 